\title{
INDUSTRY 4.0 LEARNING FACTORY DIDACTIC DESIGN PARAMETERS FOR INDUSTRIAL ENGINEERING EDUCATION IN SOUTH AFRICA
}

\author{
S.M Sackey ${ }^{1}$, A. Bester ${ }^{2 *} \&$ D. Adams ${ }^{2}$
}

\section{ARTICLE INFO}

\section{Article details}

Submitted by authors 28 Jun 2016

Accepted for publication 28 Feb 2017

Available online 26 May 2017

\section{Contact details}

Corresponding author

BesterA@cput.ac.za

\section{Author affiliations}

1 Department of Mechanical

Engineering, College of

Engineering, Kwame Nkrumah

University of Science \&

Technology, Ghana

2 Department of Industrial \&

Systems Engineering,

Faculty of Engineering,

Cape Peninsula University,

Cape Town, South Africa

DOI

http://dx.doi.org/10.7166/28-1-1584

\section{ABSTRACT}

To manage the impact of Industry 4.0 on industrial engineering (IE) education curriculum requirements, realistic teaching and learning infrastructure such as a learning factory are required. This paper scans the literature to determine Industry 4.0's principles and interactions with IE and a learning factory, surveys relevant universities by questionnaire to determine its current status and practices, and formulates didactic design parameters for an Industry 4.0 learning factory to support IE education in South Africa, making use of existing models of cyber-physical systems and learning factory morphology. In other results, the technical universities are discovered to be more positively disposed, in general terms, to developing an Industry 4.0 learning factory than are the traditional programmes which, with one exception, prefer computational facilities. Of ten universities that offer IE, only one - a traditional programme - has made significant progress towards creating an Industry 4.0 learning factory.

\section{OPSOMMING}

Om die impak van Industrie 4.0 op die bedryfsingenieurswese (BI) kurrikulum te bestuur vereis realistiese onderrig en leer infrastruktuur, soos ' $n$ "leer-fabriek". In hierdie artikel is " literatuur studie uitgevoer om die beginsels van Industrie 4.0 te bepaal en die interaksies daarvan met BI en 'n "leer-fabriek", ' $n$ vraelys is aan relevante universiteite gerig om die universiteit se huidige status en praktyke in hierdie verband te bepaal, en didaktiese ontwerp parameters vir 'n Industrie 4.0 "leer-fabriek" word geformuleer binne die Suid-Afrikaanse konteks. Hierdie formulering maak gebruik van bestaande modelle van kuber-fisiese stelsels en "leer-fabriek" morfologie. Verdere resultate toon dat universiteite van tegnologie meer positief gesind is as tradisionele universiteite, wat (met die uitsondering van een geval) berekeningsfasiliteite verkies. Van die tien universiteite wat BI aanbied, het slegs een ('n tradisionele universiteit) noemenswaardige vordering gemaak tot die oprig van 'n Industrie 4.0 "leer-fabriek".

\section{INTRODUCTION}

\subsection{Industrial engineering education: Learning factory in Industry 4.0}

The intent of this paper is to develop likely didactic design parameters for a model industrial engineering Industry 4.0 learning factory in a South African context.

Two themes with significance for industrial engineering education permeate the industrial automation and manufacturing digitisation literature at the moment. One is Industry 4.0 and the crucial role its technologies will play in how engineering curricula are developed and implemented. As currently articulated, this means understanding new requirements such as broadening of the knowledge and skill-sets of IEs, and knowing how to prepare for the digital transformation and adapt 
curricula to explore the possibilities effectively to acquire inquiry/problem-solving skills that are meaningful, adaptable, and integrative. The second, closely related to the first, is an Industry 4.0 learning factory and the pivotal role it will play in helping to develop creative, collaborative, communicative, and innovative engineers who are not only globally aware, but also possess the high and relevant digital literacy required to keep pace with the exponentially burgeoning digitalindustrial world that offers vast promise, but at the same time demands a timely critical stance to avoid unexpected shocks. A learning factory is a realistic model of a production environment that offers learners the opportunity to implement process improvements and to see the results immediately. Its main aim is to bring the real world into the education environment by providing engineering students with practical hands-on experience through real-life projects.

In response to these developments, the curriculum requirements of industrial engineering (IE) education in these smart Industry 4.0 systems, which function on massive data operations, have been discussed in Sackey and Bester [1]. In that work, the new capabilities required of industrial engineers (IEs) in Industry 4.0 in such areas as advanced analytics, novel human-machine interfaces, digital-to-physical transfer technologies, and data communication and networks were discussed. To meet these challenges, realistic practical learning facilities closely resembling real-life scenarios that are able to provide effective and efficient backstopping to theoretical instruction are necessary - meaning that there should be minimal abstraction in teaching and learning methods. In addition, Industry 4.0's status and progress as it relates to learning factory development in IE departments across the country need to be assessed. The seminal literature on Industry 4.0 does not seem to indicate that critical questions relating specifically to the IE learning factory infrastructure are being addressed. In this paper the implications of Industry 4.0 for IE practical learning requirements are explored as a first step in the design conceptualisation process. The objective is to review the interactions between IE practical learning requirements and Industry 4.0, and to formulate a didactic concept of the IE learning factory in that context. The work has the potential to advance knowledge about IE education learning factory design factors for assessing choice options.

\subsection{Overall research approach}

The approach followed in this study includes a literature review, data collection from relevant universities, analysis, and the development of a didactic background of the IE Industry 4.0 learning factory, based on general models of cyber-physical systems and learning factory morphology sourced from the literature. This approach has the advantage of being effective in casting the outcomes of the literature study properly within the IE education context.

The paper is organised as follows: Section 2 presents the research approach and its underlying rationale in detail; Section 3 gives a brief review of the literature; and Section 4 outlines a model didactic concept of the IE Industry 4.0 learning factory. Section 5 discusses the results, while Section 6 concludes the study with insightful perspectives on the results and findings.

\section{RESEARCH METHODOLOGY}

\subsection{Aim, scope, and research questions}

The primary aim of the research was to evolve a didactic concept of the Industry 4.0 learning factory tailored to IE education and research in South Africa. The objectives were to identify Industry 4.0's interactions with IE, to study the state-of-the-art in learning factories, to assess the status of learning factory development in universities offering IE, and to delineate IE learning factory didactic design principles and parameters.

To fulfil the above aim, a three-point methodology was followed: (i) a literature search, to study Industry 4.0 and to understand its practical aspects and requirements in IE education; (ii) data collection from IE departments focusing on Industry 4.0 infrastructure development and future plans; and (iii) design conceptualisation. The outcome of the literature search is a set of indicative pointers to the dimensions of the IE learning factory infrastructure required in Industry 4.0. The literature search sought answers to these questions:

1. What kind of industrial engineering practical teaching and learning infrastructure is required in Industry 4.0 environments?

2. How will emerging new dimensions of IE in Industry 4.0 that are relevant to changes on the industrial shop-floor influence the evolution of IE learning factory design? 
3. What are the key Industry 4.0 technologies, concepts and features bearing on IE that need to be replicated in a learning factory?

These questions influenced the general direction of the IE programme survey.

\subsection{Search and data-gathering strategies}

The sources searched in the literature review included journals, conference proceedings, technical reports, articles from trade journals, and company websites. The search field included a significant number of non-journal internet sources, and the search was conducted using a range of keywords and key phrases that could be relevant to learning factories and their potential impacts on IE instruction and learning. Examples included, but were not limited to, 'learning factory' and 'industrial engineering learning factory'. The term 'Industry 4.0' was sometimes combined with 'industrial engineering' and 'learning factory' in the search.

To complete the data collection process, a survey was performed with relevant universities via questionnaire to gather information about the level of Industry 4.0 infrastructure in place, future directions, general orientation to Industry 4.0, and any relevant actions being taken by IE departments. Findings from the literature were fed into the design of the questionnaire, which was distributed among all 10 industrial engineering programmes in South African universities, whether traditional or technical. Nine out of the ten institutions responded to the questionnaire. This secondary data collection exercise sought to determine:

1. Whether IE departments already employ, or have any plans to adopt, the learning factory concept.

2. If yes, then the extent of progress, including incorporation of key Industry 4.0 features.

3. If no, then the reasons and alternatives.

Answers to the above questions helped in assessing the status of Industry 4.0 infrastructure development in IE programmes across South Africa, and contributed to establishing a basis for IE learning factory didactic conceptualisation. However, it is important to point out that the primary focus of the study was not to find out the extent of the deployment of learning factories in universities, but rather to investigate their didactic design conceptualisation.

\subsection{Results, analysis, modelling, and presentation of concepts}

The data gathered were analysed to identify the general characteristics and future directions of IE learning infrastructure in the context of Industry 4.0. In the analysis, modelling, and concept presentation processes, the focus was on the practical teaching of both established core and emerging concepts in IE.

\section{LITERATURE REVIEW}

\subsection{Review of key technologies and design principles of Industry 4.0}

The literature linking IE teaching and learning infrastructure to Industry 4.0 learning factories is only now beginning to build up, given the short time it has been in existence. However, the literature on the Industry 4.0 phenomenon itself is steadily growing, and the emerging picture of a fully-fledged Industry 4.0 can be summarised as follows: In Industry 4.0, cyber-physical systems, made up of connected systems of software, sensors, machines, workpieces, and communication technologies, monitor physical processes, create a virtual copy of the physical world (physical reality meeting virtual reality [2]), and make decentralised decisions while communicating with one another, with humans, and with centralised controllers in real time as products travel through the production system [3], [4]. Over the industrial Internet of Things, these devices interact with decentralised analytics to enable decision-making and real-time responses such as predicting failure, selfconfiguration, and adapting to changes. Via the Internet of Services, both internal and crossorganisational services are offered and used [5]. Such deployment of a large number of sensors and networked machines has resulted in the continuous generation of high volumes of data, known as 'big data', which must be managed using the cyber-physical systems. Thus Industry 4.0 creates a need for many new cross-functional roles for which workers will need both information technology (IT) and production knowledge [6]. Cardinal design principles [7] of an Industry 4.0 system include modularity of structure, interoperability, virtualisation, real-time capability, and service orientation. 
The above scenario would necessitate interdisciplinary courses that integrate information technology and industrial engineering, and call for new formats for teaching and learning [6], such as a learning factory.

\subsection{The place of a learning factory in Industry $\mathbf{4 . 0}$}

Learning factories, though a relatively recent phenomenon, are increasingly being employed as an effective knowledge and competence platform for the purposes of education, training, and research within industry and academia, where many of them have sprung up across the world in the last decade [8-11]. The goals of a learning factory are usually technological and/or organisational (if used for research), or effective competency development (if used for education and training) in enabling users to master complex, unfamiliar situations [8]. The core rationale is contextualisation (i.e., providing an environment close to a real factory) and a hands-on experience for trainees.

Other arguments in favour of the Industry 4.0 learning factory include those advanced by Schuster, Groß, Vossen, Richert and Jeschke [12], who observe that transferring externally-learned content to the requirements of today's workplace is usually associated with enormous losses. They point to the inefficiencies inherent in traditional teaching and learning approaches, the complexity and dynamics of today's products and processes, and the individualisation of products in industrial customised mass production (the very characteristics of Industry 4.0) as some of the reasons for this. Cachay, Wennemer, Abele and Tenberg [13], arguing in support of this position, cite the well-known fact, proven by research, that learning by doing leads to greater retention and application possibilities than do traditional methods such as lectures, which are known to show limited effects. New learning approaches such as the IE Industry 4.0 learning factory, which seek to modernise the learning process and bring it closer to industrial practice, have thus become necessary.

\subsection{Key types of learning factory}

Abele, Metternich, Tisch, Chryssolouris, Sihn, ElMaraghy, Hummel and Ranz [8] identify two major learning factory classifications, among others: (i) the learning factory in the narrow sense (a physical learning factory), and (ii) the learning factory in the broader sense (a virtual learning factory). The former provides a real value chain for a physical product on-site, while the latter, being further away from reality, is less hands-on, but offers advantages of scalability, location-independence, and widened scope of the problems to be addressed. Of the different manifestations of learning factory described in the literature, only the above two types have been considered important to this study. Remote learning scenarios such as factory-to-classroom settings (remote teaching factory), for example, have been excluded.

\subsection{Industry 4.0 learning factory for industrial engineering education in South Africa}

Perhaps the first indications of interest in the learning factory concept in a South African university are seen in a presentation by Van Schalkwyk [16] of Stellenbosch University, in which he articulated the benefits of this new didactic approach, which he characterised as a supplementary educational method to bridge the gap between abstract lectures in universities and practical experience required in the work place. But, as Burger [14] reports, it was a senior staff person from the company Festo who later put things in the broader context of Industry 4.0. He is quoted by Burger [14] as highlighting the risks of missing the fourth industrial revolution, while stressing that Industry 4.0 will require factories of learning. The quoted Festo staff person recommends that, as Industry 4.0 slowly emerges, South African industry will have to keep pace with the changes to remain competitive in the ever-globalising world.

Another issue relates to a possible interaction of re-curriculation and the Industry 4.0 learning factory. Since Industry 4.0 is essentially about refinements to curriculum content, the requirements of re-curriculation can always be accommodated in the learning factory.

\section{SURVEY RESULTS, ANALYSIS, AND DIDACTIC DESIGN PARAMETERS FOR INDUSTRIAL} ENGINEERING INDUSTRY 4.0 LEARNING FACTORY

\subsection{Learning factory deployment in industrial engineering departments in South African universities}

Table 1 displays information from IE departments in the relevant South African universities relating to learning factory development. The naming scheme adopted here is for identification-for- 
discussion purposes only, and is not linked to any ranking scheme. A traditional university is designated $1,2,3$, or 4 , while a technical university is denoted by $A, B, C, E$, or $F$.

The table reveals an interesting pattern of differences between IE programmes in the traditional and the technical universities regarding the operation of the Industry 4.0 learning factory. Only one traditional university showed a positive attitude to operating a learning factory and was, in fact, in the process of creating one at the time of the survey. A second traditional university plans to implement the concept in virtual mode only, using industry-grade software. The others do not plan to set up one in the near future. None of the industrial engineering departments in the technical universities has a learning factory in place or under development - despite showing greater interest, generally, than the traditional programmes. Respondents from two institutions, one traditional and the other technical, learned about learning factories for the first time through the survey, and three of the six technical programmes that knew about learning factories beforehand might consider creating one in the future.

Table 1: Learning factory infrastructure development in IE departments in South African universities

\begin{tabular}{|c|c|}
\hline $\begin{array}{c}\text { IE institution: } \\
\text { Identification and type }\end{array}$ & $\begin{array}{c}\text { Does your IE department employ a learning factory? } \\
\text { Yes, and now installing (April 1, 2016) }\end{array}$ \\
\hline 1 & $\begin{array}{r}\text { No, has other alternatives, learning factory lacks real industrial, } \\
\text { organisation culture }\end{array}$ \\
\hline 2 & $\begin{array}{c}\text { No, not in physical form, but yes in a virtual mode employing } \\
\text { industry-grade software (i.e., yes, in software terms) }\end{array}$ \\
\hline 3 & No, not even heard of Industry 4.0 \\
\hline 4 & No, but planned for the future \\
\hline A & No, but may consider it in the future \\
\hline B & Treat as elective in future \\
\hline D & No, not even heard of Industry 4.0 \\
\hline E & $\begin{array}{r}\text { Yes, have plans \& potential. Skeletal structure exists (modular in } \\
\text { form, with reconfigurable machine tool), to be converted, } \\
\text { upgraded, and taken to next level. Funded through the university's } \\
\text { own internally generated funds. }\end{array}$ \\
\hline F & $\begin{array}{r}\text { and } \\
\end{array}$ \\
\hline
\end{tabular}

1, 2, 3, 4: Traditional universities offering BEng IE; A, B, C, D, E, F: Technical universities offering ND/BTech IE

\subsection{Formulation of didactic concept of industrial engineering learning factory}

A didactic concept for a learning factory that specifies what is to be learnt, how it is to be learnt, and by whom it will be learnt is required [8]. Figure 1 depicts a relational diagram between IE learners, IE knowledge and competencies, and the IE learning factory.

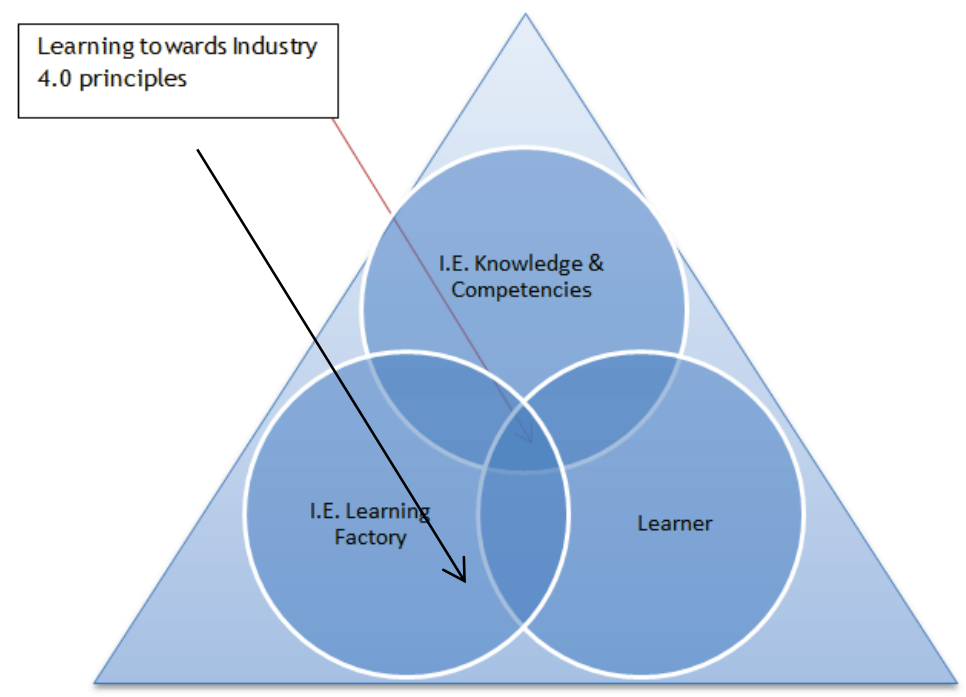

Figure 1: Industry 4.0 didactic interaction triangle, with the learning activity as the central focus of all three components 
As Figure 1 illustrates, at the intersection of the three circles there is an interconnected relationship representing the learning activity. This relationship creates a common learning object towards industry 4.0 principles, and the interactions among the three components become the foundation upon which near-real-life Industry 4.0 experiences and goals are built towards the future. In the figure, each of the three components - IE learners, IE knowledge and competencies, and the IE learning factory - will have its own internal interactions among the entities within it (e.g., interactions among the learners), which will determine one or more of the following:

1. How it responds or interacts with the others

2. What its outputs to the common interactions are, and

3. What it will demand in return from the common interactions

By virtue of its nature, the Industry 4.0 phenomenon puts pressure on all parties to develop multidisciplinary knowledge and competencies quickly, and the model projects the learning factory as the main driver/platform for achieving that end. Figure 2 further develops on the idea that the learning factory is a hub for common knowledge-creation and the shaping of teaching and learning guidelines for Industry 4.0 principles.

The figure projects the learning factory as a hub connecting all participating entities in the knowledge-creation and application process, but chiefly as a bridge that connects IE students and and common knowledge for real-world settings. Thus it represents an enriching collaborative effort among students, teaching and research academics in universities, and real-world industries. Target knowledge and competencies, when acquired, would position students to make an immediate but effective contribution to solving real-world problems facing industries. Where the concept is implemented in cooperation with industry partners, these collaborators would have the liberty to decide to include relevant IE subject matter in the learning content that is of interest to their organizations, so that students could have another opportunity to learn what is important to the real world. Teaching methods that allow the selection of subject matter and the creation of common knowledge within the learning factory towards Industry 4.0 are supported by the above model. The learning factory would accommodate IE students who are learning within a simulation mode or in a real-world context, or both.

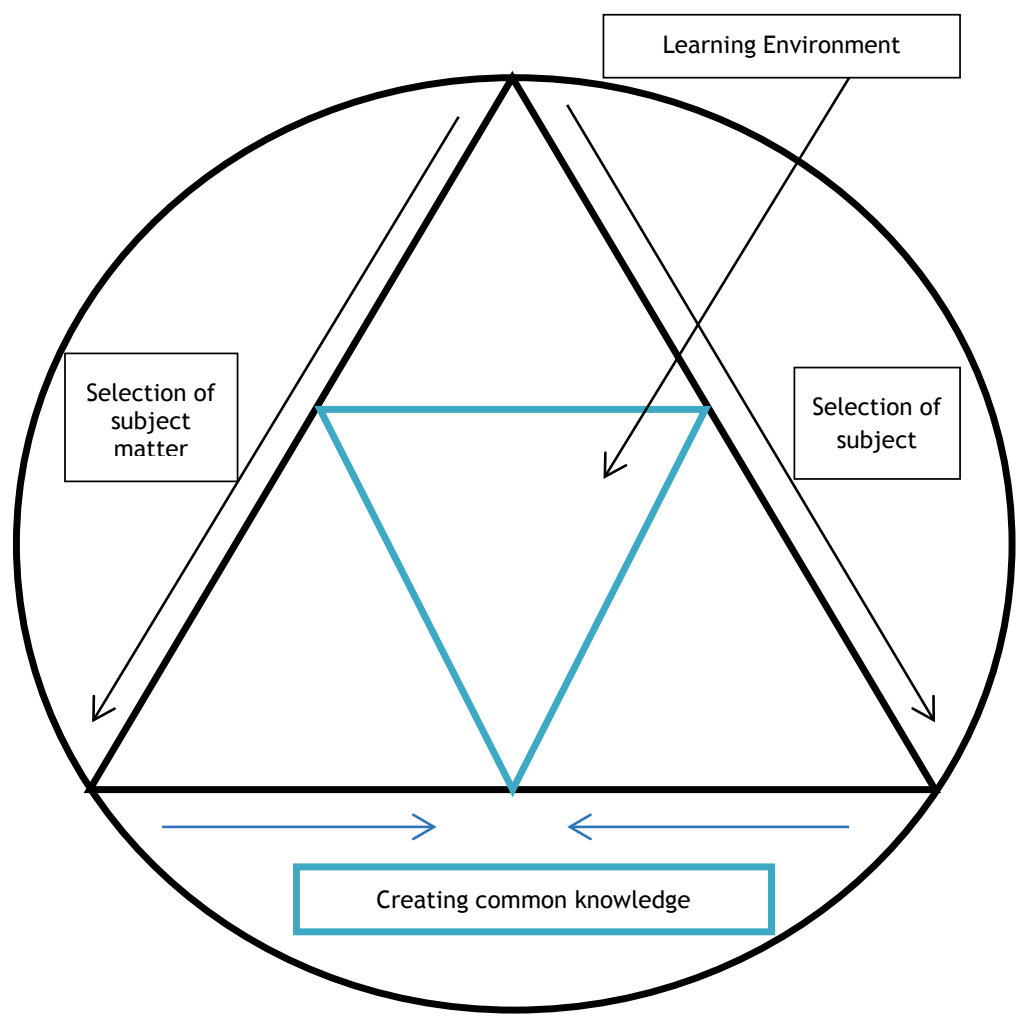

Figure 2: Industrial engineering Industry 4.0 learning factory didactic concept 
In the next sections, the authors present a more detailed delineation of the first three dimensions of the didactic concept. In doing this, the authors draw upon Lee, Bagheri and Kao's 5-C architecture for cyber-physical systems [15], Abele et al's seven-part morphology of smart learning factories [8], and the results of Section 4.1 of this paper to formulate the didactic background of a generic IE Industry 4.0 learning factory. The former (Lee et al [15]) focuses on data flows and its transformation into information and knowledge in an Industry 4.0 context, while the latter (Abele et al [8]) emphasises infrastructure morphology. Other features such as relevant IE functions and their knowledge and competency implications are then incorporated into the structure to complete the model.

\subsubsection{Didactics: What is the intended Industry 4.0 lab learning outcome for IE students?}

The learning outcome for IE students can be divided broadly into (i) professional competencies, and (ii) supporting competencies. Professional competencies chiefly cover a problem-solving capability in the technical fields, including methodological issues. Here, it is required that students develop an ability to integrate complex knowledge, skills, and attitudes for problem-solving in their future practice [11]. Supportive competencies cover teamwork and communication skills, as well as personal efficiency and organisation.

Relevant Industry 4.0 practical learning elements bearing on IE education [1] form the main basis of the learning outcome component of the didactic concept. Key areas for IE student knowledge and competency development and demonstration in an Industry 4.0 environment may include, but are not limited to:

\section{Production systems and management}

(i) Virtual plant (the learning factory) modelling by leveraging real-time data to enable realtime reaction on production process and other system problems (machine set-up, repair, maintenance) [3].

(ii) Further optimisation involving 'big data' demand and product mix analytics, machine health analytics, machine utilisation and performance analytics, work-in-process analytics, shortest route analytics, etc.

(i) Real-time inventory and logistics optimisation systems. Developing capability for identifying devices within the industrial Internet of Things (products, work-in-process, machines, equipment, workstations, etc.) using radio frequency identification (RFID) codes, tags and readers, with decentralised analytics to enable real-time responses and optimisation of production processes and supply chain systems.

(ii) Digital-to-physical transfer technologies - e.g., 3-D printing. Study, demonstration, and quantification of cycle time, inventory, and cost-reduction benefits as well as development of steps for identifying and justifying opportunities for rapid manufacturing using these technologies.

(iii) Generation, collection, and interpretation of product genealogy information.

(iv) Closed-loop integrated product and process (production) quality control and management systems involving big data analytics [5].

Physical and digital assistance systems (researching, developing, or implementing guidelines)

(i) Providing operators (students) with real-time information to improve decision-making and work procedures - e.g., aid in selecting parts in a logistics centre in the learning factory, or sending repair instructions over mobile devices or augmented-reality glasses on how to replace a particular part on-site (in the learning factory or, e.g., a mechanical engineering department machine workshop, for practice).

(ii) Virtual training systems, using a realistic, data-based 3-D environment with augmentedreality glasses to train plant personnel (students). They can learn to interact with machines by clicking on a cyber-representation of a system, or change parameters and retrieve operational data and maintenance instructions.

(iii) Human-robot collaboration (techniques for optimising human-robot collaboration) involving demonstrating or developing rules and principles to guide robot cooperation with humans, robot-learning from humans, and to cover safety issues in human-robot interaction.

(iv) Design of multi-machine worker assistance systems [6]. 
Data acquisition, conversion, interpretation, decision-making, and feedback processes

Demonstration of the workings of devices enriched with embedded computing, connected using standard technologies (e.g., Profibus) and ethernet systems [15] for communication and interaction with one another and with centralised controllers [3].

(ii) Cyber-physical systems [15]. Data flow, conversion, and entity interactions, with the cyberphysical systems hub exchanging data with sensors, actuators, drivers, programmable logic controllers (PLCs). Smart connections: Intelligent sensor data from products, materials, machine components, or data from machine controllers and networked systems - e.g., Enterprise Resource Planning, or manufacturing execution systems. Interfacing the cyberphysical systems with the analytics function. Data conversion: data-to-information conversion using smart analytics, to determine entity status, multi-dimensional correlations, and performance. Cyber: Specific analytics for better insight into individual elements among a whole fleet, and self-comparisons. Cognition: generation of thorough knowledge of the system, and its presentation to aid and support decision-making. Configuration: Selfconfiguration, self-adapting, self-correction, preventive actions.

(iii) The cloud. Demonstrations involving the use of cloud-based software for some enterprise and analytics applications, as well as production-related undertakings. Deploying machine data and functionality to the cloud, to enable data-driven services for production systems and control processes [15]. (Developing this capability might require partnership with a vendor of manufacturing-execution systems that offers cloud-based solutions).

Systems perspective and integration

(iv) Top floor/shop floor information systems

Learning factory as a holistic model of a manufacturing plant, from the top level Enterprise Resource Planning to the field level, to be used as a basis for demonstrating universal dataintegration networks and collaboration platforms that create truly automated value chains and a common workspace for design and manufacturing for exchanging product and production data among multiple units.

\subsubsection{Didactics - Learning environment}

A learning factory provides the essential learning environment that fulfills the requirements represented in Figures 1 and 2. It provides an active, learner-centered, and competence-orientated didactic setting with the aim of acquiring knowledge and skills for developing effective technical problem-solving skills in specific application contexts. Guidelines for the Industry 4.0 IE learning factory can be summed up as follows [8]:

i. Knowledge should be presented in a structured way and within the context of its practical application.

ii. The learners should gain effective specialist problem-solving competencies.

iii. The process of knowledge acquisition should include central competences in self-directed learning.

iv. Student motivation for learning should increase through the opportunity to test and experiment with ideas in an environment close to an industrial setting.

Comparing these with the intended learning outcome of IE education given in Figures 1 and 2 and in Section 4.2.1, the potential of the learning factory to enhance modern IE engineering education becomes evident.

Within the framework of a modified version of Abele et al's seven-part morphology of learning factories [8], the table below presents a five-part (simplified and customised) structure answering the how and by whom parts of the didactics specification.

\subsubsection{Philosophy and overall design principles of Industry 4.0 IE learning factory}

Cardinal design principle: The facility is to reflect the key functional features and likely elements i.e., the capabilities - of an Industry 4.0 system. These include: modularity of structure, for increased flexibility; interoperability, whereby entities communicate seamlessly with each other; virtualisation, with a strong emphasis on simulation and decentralised decision-making; real-time capability, for quick response; and service orientation aiming to give customers virtual guidance to perform self-service [5]. Since many courses or subjects are expected to be taught or studied in the learning factory, flexibility is paramount. 
Table 2: Five-part IE Industry 4.0 learning factory morphology with didactic concept

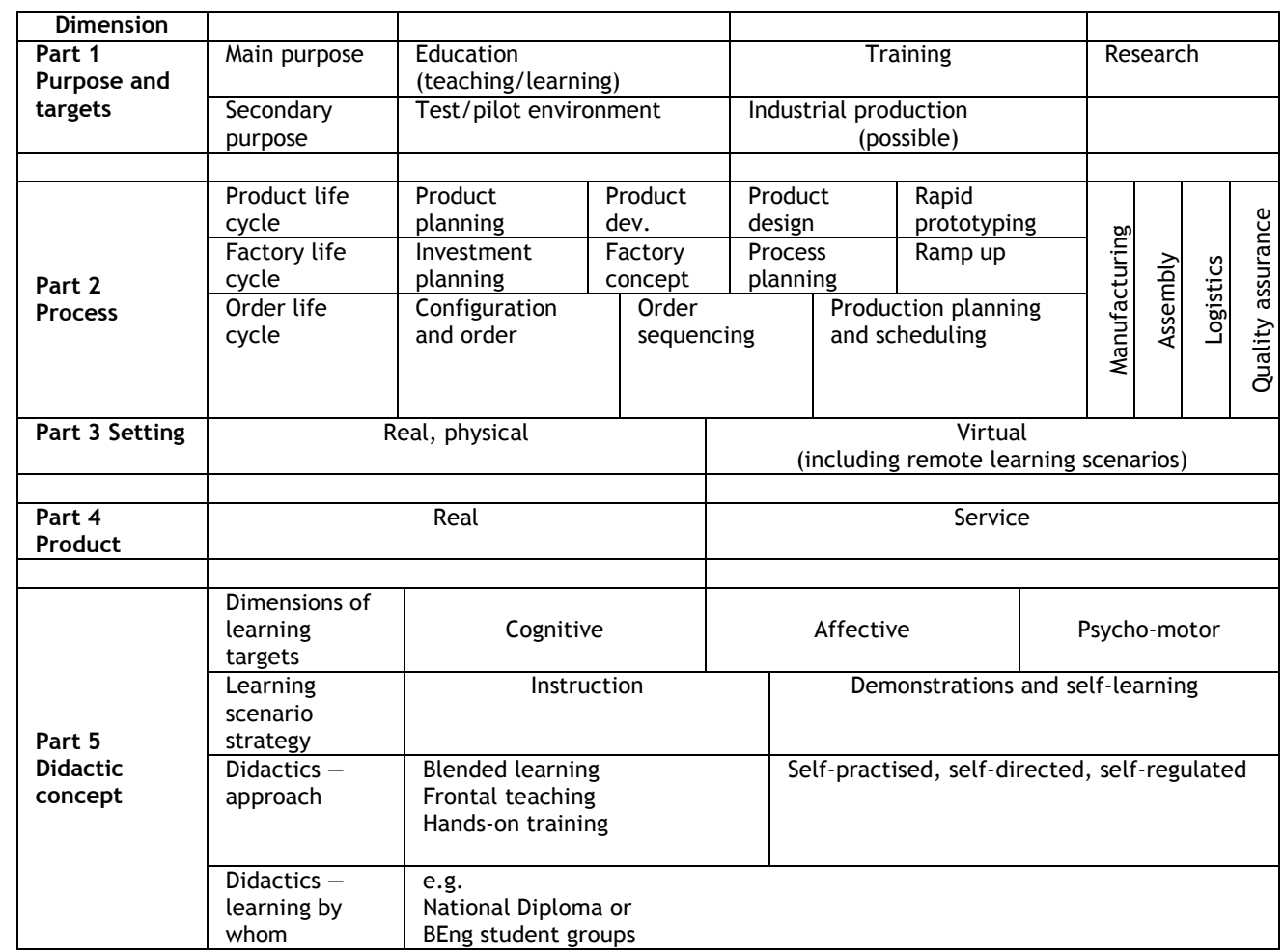

\subsubsection{Operation of representative demonstration models}

The overarching consideration in Industry 4.0 is the automated gathering, processing, and communication of data in a linked industrial or production environment. The authors present two example demonstration models. It is assumed that a linked production environment is in place in a learning factory, where interactions between humans (students), automation solutions, and information and communication technologies exist and can be demonstrated in accordance with Section 4.2.3.

Demonstration model 1: Cyber-physical systems interfacing and interconnections. Intelligent data management, analytics, and entity optimisation

Broadening and extending Lee et al's format for the operation of prognostic health monitoring systems [15] to cover all relevant entities in an industrial engineering Industry 4.0 learning factory setting, students could, for example, be required to:

- Understand and be able to configure the different interfaces of the information technology components and factory planning software (e.g., Enterprise Resource Planning) in order to bridge the data sources in a seamless way.

- Know how to establish advanced connectivity, through the entity-cyber interfaces, between the entity analytics and the cyber-level infrastructure to allow entities to register into the network for information exchange.

- $\quad$ Apply algorithms to track changes in each entity's status.

- Demonstrate and track the full sequence and cycle of the data-to-information-to-knowledgeto-insight process as a platform for self-configurability or self-correction, or self-optimisation in the learning factory to achieve optimised production management plans [8].

\section{Demonstration model 2: Data consistency in product life-cycle processes}

A special student project could cover part 2 of the learning factory morphology (Table 2) -i.e., product life cycle processes, encompassing product planning, product development, product design, rapid prototyping, manufacturing, assembly, logistics, and quality assurance to demonstrate the 
importance of data consistency from product design through manufacturing to assembly, and the potential of information and communication technologies for decentralised production and logistics.

\section{5}

DISCUSSION

The Industry 4.0 IE learning factory didactic model presented in this work is only one possible concept; like all engineering design, other equally good models are possible, the exact form depending on the particular application scenario. What this work has sought to do is to delineate a didactic background framework for an Industry 4.0 IE learning factory to contribute to the practical instruction of students in essential concepts of Industry 4.0 that bear on the IE function. The philosophy is that learning factory could be used as an effective preparatory training ground for real-world factories. Likewise, the design principles outlined in the study do not all have to be employed in any single learning factory design project. In each case, a strategy should be worked out to suit the given application scenario. However, the key Industry 4.0 features of interoperability, real-time capability, massive data flows, and cyber-physical systems must be addressed in the learning factory. The complete realisation of Industry 4.0 learning factory's full potential comes only when the concept is implemented in cooperation with an enthusiastic and willing industry partner, even though this feature has been omitted from the proposed morphology.

It is not altogether surprising that the technical/technology programmes showed greater interest in the Industry 4.0 learning factory. The argument put forward by the respondent from one of the traditional universities - that his department decided not to go the way of the learning factory because, in their view, a learning factory lacks an internal company culture - may be understandable to some extent; but it is important to point out that an Industry 4.0 learning factory offers far more than simplistic hands-on exposure. It represents a modern didactic platform for developing an immediate and effective integration of knowledge and competencies, and imparting them to students to meet essential education and training requirements such as developing their creative, collaborative, communicative, and innovative potential to meet the ever-rising expectations of industry for new employees who are able to make immediate contributions to their organisations. In addition, it is widely recognised that technology is now playing a critical role in how curricula are being developed; and with the advent of Industry 4.0, many more demands will be placed on the IE function to deliver interdisciplinary capabilities and the high levels of digital literacy required to keep pace with the exponentially burgeoning digital world. It also means knowing how to access content knowledge efficiently and effectively, and to acquire inquiry/problem-solving skills that are meaningful, adaptable, and integrative. The Industry 4.0 learning factory represents an opportunity to offer students an effective platform for developing these capabilities as close as possible to a real industrial setting.

\section{CONCLUSION}

The real-time nature of the inputs and the data-driven outputs of Industry 4.0 and its smart, automated disposition represent a major departure from traditional industrial systems. The broad nature of its interactions with industrial engineering requires multidisciplinary capabilities; and these would be most effectively taught and learned through a realistic practical learning infrastructure such as a learning factory.

In conclusion, a didactic concept of the IE Industry 4.0 learning factory has been formulated, with relevant learning outcomes. It offers students an opportunity to learn the practical aspects of courses, including the integrative product emergence process, in a more effective and efficient manner.

That only one traditional institution has shown any interest in the Industry 4.0 physical learning factory - while the others do not even have any plans to do so - may not sound positive enough. Given what is at stake, the benefits of a learning factory would seem to outweigh its downside. For example, implemented in cooperation with an industry partner, a student learning factory team could become, for a small business enterprise, the engineering workforce for a semester or two, while for other firms the team could help to develop new ideas for improving current practices both of which could impact the company's bottom line. Other benefits, articulated by Van Schalkwyk [16] of Stellenbosch University, include: 
1. Providing comprehensive and lasting integrative IE education.

2. Offering students similar-to-real-life experiences that are not included in current educational methods.

3. Providing experimental and practical projects that help IE students - and, more importantly, future engineers - to have an education that benefits industries by providing more experienced entry-level engineers, thus reducing the cost of pre-job employee training.

These, clearly, are benefits that would attract all stakeholders in the industrial engineering discipline.

Future research could focus on guidelines for methods to delineate the roles and functions of the various IE qualifications within the IE Industry 4.0 learning factory context.

\section{ACKNOWLEDGEMENT}

The authors gratefully acknowledge the Faculty of Engineering of the Cape Peninsula University of Technology, Cape Town, South Africa, for fully supporting this work.

\section{REFERENCES}

[1] Sackey, S. M. \& Bester. A. 2016. Industrial engineering curriculum in Industry 4.0 in a South African context, South African Journal of Industrial Engineering, 27(4), pp 101-114.

[2] Schuster, K., Groß, K., Vossen, R., Richert, A. \& Jeschke, S. 2015. Preparing for Industry $4.0-$ collaborative virtual learning environments in engineering education, The International Conference on $E$ Learning in the Workplace (ICELW), New York, NY, USA, June 10-12, pp. 1-6.

[3] Rüßmann, M., Lorenz, M., Gerbert, P., Waldner, M., Justus, J., Engel, P. \& Harnisch, M. 2015. Industry 4.0: The future of productivity and growth in manufacturing industries. [Online] Available at: https://www.bcgperspectives.com/content/articles/engineered_products_project_business_industry_40 _future_productivity_growth_manufacturing_industries/[Accessed 01 Sep-2015].

[4] Khaitan, S.K. \& McCalley J.D. 2015. Design techniques and applications of cyber physical systems: A survey, IEEE Systems Journal, 9(2) pp. 350-365.

[5] Baur, C. \& Wee, D. 2015. Manufacturing's next act, Insights and Publications. [Online] Available at: http://www.mckinsey.com/business-functions/operations/our-insights/manufacturings-next-act [Accessed 05 January, 2016].

[6] Lorenz, M., Rüßmann, M., Strack, R., Lueth, K.L. \& Bolle, M. 2015. Man and machine in Industry 4.0. [Online] Available at: https://www.bcgperspectives.com/ content/articles/technology-businesstransformation-engineered-products-infrastructure-man-machine-industry-4/ [Accessed 08 December, 2015].

[7] Hermann M., Pentek T. \& Otto B. 2015: Design principles for Industrie 4.0 scenarios - A literature review, Technical University, Dortmund. [Online] Available at: http://www.snom.mb.tudortmund.de/cms/de/forschung/Arbeitsberichte/Design-Principles-for-Industrie-4_0-Scenarios.pdf [Accessed: 04 Jan-2016].

[8] Abele, E., Metternich, J., Tisch, M., Chryssolouris, G., Sihn, W., ElMaraghy, H., Hummel, V. \& Ranz, F. 2015. Learning factories for research, education, and training, Fifth Conference on Learning Factories, Procedia CIRP, 32, pp. 1-6.

[9] Badurdeen F., Marksberry P., Hall A. \& Gregory, B. 2010. Teaching lean manufacturing with simulations and games: A survey and future directions, J. Simulation \& Gaming, 41, pp. 465-486.

[10] Riffelmacher, P. \& Westkämpfer, E. 2009. Arbeitsvorbereiter und Produktionsleiter richtig qualifizieren - Lernfabrik - advanced industrial engineering, Journal of Economic Factory Operation, 104, pp. 817-821.

[11] Kreimeier, D., Morlock, F., Prinz, C. \& Pollmann, J. 2013. Practical learning within a manufacturing environment - Learning factory impacts holistic production systems and lean management, Industrial Engineering, 1, pp. 26-29.

[12] Schuster, K., Groß, K., Vossen, R., Richert, A. \& Jeschke, S. 2015. Preparing for Industry $4.0-$ collaborative virtual learning environments in engineering education, The International Conference on ELearning in the Workplace, (ICELW), New York, NY, USA, 10-12 June, pp. 1-6.

[13] Cachay, J., Wennemer, J., Abele, E. \& Tenberg, R. 2012. Study on action-oriented learning with a learning factory approach, Procedia - Social and Behavioural Sciences, 55, pp. 1144-1153.

[14] Burger, S. 2015. Industry 4.0 requires factories of learning, Creamer Media Engineering News. [Online] Available at: http://www.engineeringnews.co.za/article/ industry-40-requires-factories-of-learning-festo-2015-04-24/rep_id:4136 [Accessed 12 January, 2016].

[15] Lee J., Bagheri B. \& Kao, H. 2014. A cyber-physical systems architecture for Industry 4.0 manufacturing systems, Manufacturing Letters, 3, pp. 18-23.

[16] Van Schalkwyk, T.D. 2013. Introduction to learning factory concepts: A Stellenbosch University case study. Conference abstract and presentation for SAIIE-2013, Spier, Stellenbosch. 